UDK: 811.163.41'367.62

$811.511 .141^{\prime} 367.62$

81 '37

DOI: https://doi.org/10.18485/25bghun.2021.ch1

\title{
ANDRIĆ EDIT
}

Újvidéki Egyetem, BTK, Magyar Nyelv és Irodalom Tanszék

\section{A 'fehér' szín a magyarban és a szerbben}

\begin{abstract}
Összefoglaló
Az ember univerzális tulajdonsága, hogy a látószerve segítségével érzékelni tudja a fényt s ezzel együtt a színeket is, amelyek körülveszik őt. A színérzék alapján semleges és tarka színeket különböztetünk meg. A dolgozat az akromatikus színek egyikével foglalkozik, illetve annak megnyilvánulásaival a magyar és a szerb nyelvben. Külön kitér a színt megnevező lexémák szemantikájára, kognitív jellemzőire, derivációs potenciáljára és a vele alkotott frazeológai egységek elemzésére, azzal a céllal, hogy rámutasson a két nyelvben tapasztalható hasonlóságokra és különbségekre.
\end{abstract}

Kulcsszavak: színek, árnyalatok, fehér, beo, kontrasztív elemzés, magyar nyelv, szerb nyelv.

\section{Bevezetés}

A szín mint sajátos, de ugyanakkor univerzális vizuális jelenség régóta foglalkoztatja az ember fantáziáját. Sokféleképpen közelíthetünk a tanulmányozásához: a természettudományok felől (vizsgálhatjuk fizikai sajátosságait, intenzitását), a társadalomtudományok szemszögéböl (foglalkozhatunk kognitív jellemzőivel, percepciójával, az ember lelkivilágára gyakorolt hatásával), de a humán tudományok és a müvészetek oldaláról is (szimbólumrendszerével, kifejező potenciáljával) s nem utolsósorban nyelvészeti indíttatással is. Az utóbbi diszciplína terén leginkább a színek nyelvenkénti megnevezése motiválja az izgalmas elemzéseket. A színneveket is vizsgálhatjuk 
különböző módon: általános nyelvészeti szempontból, kutathatjuk az egy nyelven belüli színekkel kapcsolatos kifejezéseket, de összehasonlító és kontrasztív nyelvészeti fejtegetéseket is megkockáztathatunk egy vagy több rokon vagy különböző nyelvcsaládba tartozó nyelv kapcsán. Ilyen vizsgálódások során sok minden kiderül az összehasonlított nyelvek rendszeréről, olykor még tévhiteket is megcáfolhatunk velük.

Ezúttal a 'fehér' színt járom körül kontrasztív megközelítéssel, éspedig különböző módon elemzem magát a színt és a színárnyalatokat megnevező kifejezéseket a magyar és a szerb nyelvben: megvizsgálom a jelenség szótári definiálását, a színnév etimológiáját, az árnyalatmegnevezések jellemzőit, a derivációs tartományát, továbbá érintem a fehérrel kapcsolatos frazeológiát a két említett nyelvben, valamint a gyakori szókapcsolatokat, kollokációkat.

\section{A 'fehér' színtartománya}

A 'fehér' valójában nem fizikai értelemben vett szín, ezért sokan tagadják színi mivoltát, ugyanakkor sokkal több is annál, mivel a fehér fény tartalmazza a spektrum összes színét, pontosabban annak bontásával keletkeznek a tarka színek, amelyek egyben az alapszínek is. Elöször is tekintsük meg, hogy a vizsgálódásunk tárgyát képező kifejezés és annak szerb ekvivalense milyen jelentéssel bír az értelmező szótárakban.

FEHÉR I. mn 1. Olyan színü mint amilyen a tiszta hó [...] | Ösz, ezüstfehér. 2. Világos színủ [...] | színtlen, átlátszó 3. irod Szüziesen tiszta, ártatlan [...] 4. tört Ellenforradalmi [...] II. fn 1. A legvilágosabb semleges szín | Fehér festék. [...] | fehér ruha 2. Fehérbor 3. Fehér (nem színes bőrü) ember 4. sp biz Sakkban: világos. 5. Vminek a fehér része 6. tört a) Ellenforradalmár b) Fehér gárdista (ÉKsz.)

БЕО 1. а. који је боје снега, млека и сл. [...] б. саграђен од камена такве боје или окречен таквом бојом; уопште које се белином 
истиче од средине, позадине [...] в. сед, пепељаст; сребрнаст; сјајан [...] г. светлоплав, светао [...] д. који је светле, отворене боје у односу на нешто тамне боје исте врсте [...] 2. а. светао, сјајан, блештав; усијан, ужарен [...] б. јасан, видан, светао, пун светлости, обасјан светлошћу [... 3. фиг. а. чедан, невин, безгрешан, частан [...] б. добар, позитиван у моралном смислу (обично уз „црн” као супротност) [...] в. срећан, угодан, пријатан [...] г. оптимистички, ведар [...] 4. а. празан, неисписан; брисан од стране цензуре [...] б. који је без тачака, празан (о доминама) [...] 5. саставни део поједних назива, обично ботаничких и зоолошких термина [...] 6. у именичкој служби а. $\boldsymbol{м}$ пол. контрареволуционар, противних комунистичке револуције б. онај који је обучен у бели дрес (спортиста) в. онај који игра белим фигурама (у шаху) г. бело одело, бела одећа, жена у белом д. ж мед беона ђ. беоњача е. бела скрама на језику ж фиг. оно што је добро, позитивно, лепо ${ }^{1}$. (RSJ)

A szerb értelmező szótár részletezőbb a jelentések definiálásban, azonban a lényeges dolgokban mindkét nyelv megegyezik. A fehér - beo elsődleges jelentését a 'hó’ színével azonosítjuk (a szerbben még a 'tejjel' is). Az első értelmezés tartalmazza az 'ősz' és az 'ezüstszín' jelentést is. A fehéren kívül a szín hiányát vagy a világos árnyalatokat is jelölheti a dolog sötétebb (rendszerint 'fekete', esetleg 'barna') változatával szemben. A szerbben egykor a 'világos'

\footnotetext{
${ }^{1}$ FeHÉR 1.a. amely olyan színű mint a hó, a tej stb. [...] b. ilyen színű kőből épült vagy ilyen színűre meszelt épület; amely fehérségével kitünik a környezetéböl [...] c. ősz, hamuszínü; ezüstös, fényes [...] d. világoskék, világos [...] e. valamilyen tárgy vagy jelenség világosabb változata, a sötétebbhez vagy más színűhöz viszonyítva [...] 2.a. világos, fényes, csillogó, ragyogó; izzó, parázsló [...] b. látható, világos, fényes, fénnyel teli [...] 3. átv a. ártatlan, bűntelen, becsületes [...] b. jó, pozitív, erkölcsös (leginkább a 'fekete' ellentéteként) [...] c. boldog, kellemes [...] d. derüs, vidám [...] 4.a. üres, kitöltetlen; a cenzúra által törölt [...] b. pont nélküli, üres (a dominóra vonatkoztatva) [...] 5. növényi és állati terminusok részeként [...] 6. fönévi funkcióban a. $m$ pol ellenforradalmár, a kommunista forradalom ellensége b. aki fehér mezben van (sportoló) c. fehér sakkfigurával játszó személy d. fehér ruha, öltöny e. forv hályog f. szemfehérje g. fehér lepel a nyelven e. fig az ami jó, pozitív, szép. (Fordította a tanulmány szerzöje).
} 
szinonimájaként tartották számon a beo melléknevet. Ivić a bela kafa (= fehér kávé, magyarul tejeskávé), belo vino (= fehérbor), beo ten (= fehér bőr) szintagmákkal példálózik, ahol a beo tulajdonképpen a kávé esetében 'barnát', a bor esetében 'sárgát', és a bőrre vonatkoztatva 'rózsaszínt' jelent, illetve a tárgy lehetséges színei közül a legvilágosabbat, a fehérhez legközelebb állót reprezentálja (Ivić 1995: 14). A 'fehér' ezeknél tehát világos mivoltával áll szemben más, nem semleges színekkel, éspedig a barnával, pontosabban a feketével (a kávé esetében), a vörössel (a bor példájában), valamint a fekete/sárga/vörös színekkel, amikor az emberi testszínre vonatkoztatjuk. Ehhez a sorhoz még hozzá kívánkozik a szerbben a beli luk és a crni luk (= fehér hagyma és fekete hagyma, magyarul fokhagyma és vöröshagyma) páros, amely rávilágít a nyelvek közötti percepciós különbségekre, pontosabban felveti a kérdést, hogy valójában miért 'fekete' a szerbben és 'vörös' a magyarban a hagyma. A szerbben ez egyértelmünek tünik: a 'fokhagyma' terminusban szereplő 'fehér' színnel állítja szembe a 'feketét' (beli luk - crni luk), a magyarban viszont, tekintettel arra, hogy a fokhagyma megnevezésben nem szerepel színnév, nem nevezhetjük meg annak komplementer párját, így a vöröshagyma héjának színéről kapta a nevét.

Ivić hívja fel a figyelmet arra is, hogy a beo melléknév a szerbben megtartotta a fényességgel, ragyogással kapcsolatos eredeti szemantikáját is, ez kihat a szín höérzettel kapcsolatos metaforikus jelentéstöbbletére, ezért találjuk meg az 'izzó', 'parázsló' mellékneveket a jelentésmeghatározások között.

Jelentős helyen áll mindkét nyelvben az átvitt értelem, amely a szüzességre, ártatlanságra, erkölcsre vonatkozik. A magyarral ellentétben a beo melléknév még pozitív hangulatot és érzelmeket is kifejezhet, azt, hogy valaki boldog, derülátó, vidám, vagy hogy valami kellemes. A szerb szótárban külön pontban szerepel a különböző értelemben használatos 'hiány, ür, üresség' jelentés.

Főnévi funkcióban a magyarban a fehér elsősorban a szín nevére és a festékre vonatkoztatható, de a fehér bőrü embert is jelölheti. Politikai értelemben az 'ellenforradalmár' jelentés megtalálható mindkét nyelvben. A szerbben még fehér ruhás személyt vagy a sportban fehér mezes játékosokat jelent. Csak nőnemü 
alakja egykor a szem fehérjét is jelölte, ma azonban már a származékszava, a beonjača használatos ilyen értelemben.

A magyar színtan.hu (http://www.szintan.hu/) portálon a 'fehér' színtartományában 79 megnevezés szerepel. Ez természetesen nem azt jelenti, hogy ennyi különböző színárnyalat létezik, hanem inkább azt, hogy a fehér szín intenzitásának kifejezésével más-más tárgyra, jelenségre asszociálunk a fehér szín kapcsán. A dolgozat mellékletében közlöm a szóban forgó színmegnevezéseket színkódjukkal, valamit angol és szerb nyelvü megfelelőikkel együtt, éspedig két külön táblázatban. Az egyik az azonos, \#FFFFFF, RGB: 255255 255, H:- ${ }^{2}$ jelzéssel rendelkező, ún. tiszta fehéreket tartalmazza, a további, ezektől némiképpen eltérő árnyalatokat a második táblázat szemlélteti.

A 'fehér' a korpusz alapján lehet: tiszta, ragyogó, vakító (hófehér), továbbá lehet tört (fal-, klór- és nyárfehér), tört/meleg (alabástrom-, gyapjú-, gyöngy-, és papírfehér), piszkos (gipsz-, mészfehér), valamint hideg (opál- és márványfehér) és meleg (bárány-, kagyló-, kókusz-, ón-, tej-, tejfel- és zsírfehér). Felületszínként említhetjük a következőket: antik, ezüst (ezüstszín), fényes (porcelánfehér), matt (gyapot-, kréta-, vattafehér) tompa (litopon- és lisztfehér), és opálos (márvány-, porcelánfehér). Ezenkívül átmenetet is képezhet valamely más alapszín és a fehér között: sárgásak (elefántcsont-, gólya-, krizantém-, lárva-, marcipán- és sárfehér) szürkések (tojáshéjszín), kékesek (hold-, patyolat-, és télfehér), zöldesfehér (bodzafehér).

A szerb nyelvre kevésbé jellemző szóösszetételek képzése, ezért az említett magyar árnyalatok szerb megfelelőinek megalkotásában több különböző megoldáshoz folyamodhatunk. Egyrészt az analitikus módot, körülírást, illetve hasonlatokat alkalmazhatunk: beo poput sna (= fehér, mint az álom), beo kao inje (= fehér, mint a dér). Amennyiben a hasonlítási alapul szolgáló főnév jelentése lehetővé teszi, akkor olyan kötőszavas összetételként is fordíthatjuk, amelynek

\footnotetext{
${ }^{2}$ A színkódok tartalmazzák a színminta adatait: \# a hexadecimális jelzését; az RGB (red-greenblue), a számítógép által megjeleníthető alapadat; a H: (hue), az emberi színérzet paramétereit. A semleges színeknek (fehér-fekete-szürke) nincs színezete.
} 
utótagjában a beo melléknév szerepel: čipka-bela (= csipke-fehér), platno-bela (= vászon-fehér). A legtermészetesebb azonban a jelzős szerkezetek alkalmazása, ha az asszociáció alapját képező főnévből melléknév hozható létre: mramorno bela (= márványos fehér), biserno bela (= gyöngyfehér).

Alaktani szempontból a 'fehér' alapszínen kívül a többi árnyalat mind szóösszetétel, előtagjukat konkrét dolgokat vagy elvont fogalmakat jelölő főnév képezi, utótagjuk pedig vagy a fehér szavunk, vagy az annak fölérendelt fogalom, a szín. Eredetüket tekintve legföképp asszociatív jellegüek, s ebből adódik az, hogy az előtagban szereplő fogalom egyben az asszociáció alapját is képezi. Vannak köztük természeti jelenségek: harmat, dér, felhö, hab, hó, gleccser, sár, olyan állatok, amelyeknek szőre vagy valamely jellegzetes testrésze fehér (vagy az is lehet): bárány, elefánt, hermelin, kagyló, lárva, illetve szép számban jelentkeznek madárnevek: galamb, gólya, hattyú, kócsag, toll. Talán a legtöbb fehér árnyalat nevét a növénynevek hívták életre, közülük is a legszámosabbak a virágok: gyöngyvirág, jázmin, krizantém, liliom, magnólia, margaréta, orchidea, de a listán növények részei, illetve termései is szerepelnek: szirom, bodza (virág), kókusz, nyár(fa). Továbbá motivációs alapul szolgáltak az olyan élelmiszerek, amelyek kitünnek fehérségükkel, ezek a cukor, liszt, só, tej, tejfel, de a sárgás árnyalatúak között is van néhány: marcipán, tojás(héj), zsír. Anyagnevek is szerepelnek szép számban, ilyenek az alabástrom, a gipsz, a kréta, a kristály, a litopon, a márvány, a papír, a porcelán. Állaguktól, összetételüktől függően kiegészítő információkkal is szolgálhatnak: fényességet, hidegséget, keménységet, tisztaságot, áttetszőséget, porhanyósságot fejeznek ki. Néhány elvont dolog, képzeletbeli lény is elöfordul: álom, angyal, tündér, valamint földrajzi nevek is motiválták az árnyalatnevek kialakulását: Himalája, Alpok, de ennél több a kémiai anyag indíttatású elnevezés: barit, klór, ólom, ón, titán, s itt kell megemlíteni a drágaköveket is: gyémánt, gyöngy, opál, továbbá a textíliafajtákat és a ruhaféléket: csipke, fátyol, gyapjú, gyapot, gyolcs, patyolat, vászon, vatta. 
A felsorolt fehér árnyalatok különböző kontextusban fordulnak elő. Legtöbbjüket általános funkcióval használjuk, sok mindenre vonatkoztathatóak, mások viszont csak bizonyos tárgyak, fogalmak jellemzésére specializálódtak. Így például néhányukat inkább csak az arcszín vagy az emberi haj színére használjuk: alabástromfehér (kicsit régies, akkor volt divatban, amikor a fehér bőr volt a szépségideál, egyúttal jelölve a fehérséget és a hidegséget is), falfehér (sápadt arcú), habfehér (az általánosságban használt könnyed fehér árnyalat mellett a bőrszínre is vonatkozik), halottfehér (nagyon sápadt, beteges arcú), ilyenek még a hattyúfehér, krétafehér, lárvafehér, liliomfehér, márványfehér, tejfehér (nő és gyermek bőrének fehérségét hangsúlyozzák), az emberi őszülő hajszínt a következő fehér árnyalatokkal szoktuk megnevezni dérfehér, hófehér, nyárfehér. Pigmentnévként tartják számon a barit-, ólom- és titánfehért, divatnévként pedig az alpin-, gleccser-, Himalája-, kristály-és magnóliafehéret.

\section{A deriváció}

Még Berlin és Kay (Berlin, Brent-Kay, Paul 1969) a színekkel foglalkozó, ma már megkerülhetetlennek számító müvükben lefektették az alapszíneket megnevező lexémák univerzális kötelező feltételeit, amelyekhez 98 különböző nyelv színneveinek az összehasonlítása révén jutottak el. Az egyik elv a színnevek továbbképezhetősége, az, hogy más szavakat, mellékneveket, főneveket, igéket és határozószókat deriválhatunk belölük. A nyelvek többségében a színnév ugyanis egyben melléknév is és főnév is lehet, a mondatbeli viselkedésük, illetve a kontextuális tényezők szabják meg, hogy konkrétan milyen szófajként fordulnak elő. Így van ez a magyar és a szerb nyelvben is, hiszen már a fenti definiálás során is láthattuk ezt a kettőséget: a magyarban római kettessel vannak jelölve a fónévi jelentések, míg a szerbben a hatodik jelentés alpontjai tüntetik fel a fonnévi funkciójú értelmeket.

A két nyelvben további melléknevek, főnevek, igék és határozószók is képezhetők a fehér szótőből és annak szerb megfelelőjéből. A magyar képzők következetesebb és átláthatóbb rendszert képeznek a nyelv agglutináló jellégéből 
adódóan, ezért természetes, hogy a képzett szavak száma a magyarban nagyobb. Legtöbb melléknév hozható létre ily módon (37), majd főnév (21), gyakorisági szempontból harmadik helyen a határozószók (17) vannak, és végül az igék (11) következnek.

A képzett szavak nagy része másodlagos és harmadlagos deriváció eredménye. Ilyenkor mindig a derivátum képzésére szolgáló toldalékok állnak a szó végén. Melléknévképzés esetében gyakori a denominális, de a deverbális képzés is. Ha megfigyeljük ezek szerb fordítását, láthatjuk, hogy amennyiben szintén képzett szó az ekvivalens, azok nagy része kombinált, prefixumos-szuffixumos képzés eredményei. Sokszor azonban, ha pontosan szeretnénk érzékeltetni a magyar kifejezés minden mozzanatát, a szerbben körülírást kell alkalmazni. Megjegyezhetjük azt is, hogy a magyar képzőrendszer sokfélesége következtében fordításkor kénytelenek vagyunk azonos megoldásokat alkalmazni a szerbben.

\section{Melléknévképzés}

\begin{tabular}{|c|c|c|c|c|}
\hline Szó & \multicolumn{3}{|c|}{ képzők } & szerb fordítás \\
\hline fehérded & \multicolumn{3}{|c|}{-dad/-ded } & beličast \\
\hline fehérecske & \multicolumn{3}{|c|}{-cska/-cske } & $\begin{array}{l}\text { malo belo, belkasto } \\
\text { (deminutiv) }\end{array}$ \\
\hline fehérecskés & \multicolumn{2}{|c|}{-cska/-cske } & $-S$ & beličast \\
\hline fehéredö & \multicolumn{2}{|c|}{-odik/-edik/-ödik } & -ó/-ő & $\begin{array}{l}\text { postepeno postaje beo, } \\
\text { izbeljuje se }\end{array}$ \\
\hline fehéredös & $\begin{array}{l}\text {-odik/ } \\
\text {-edik/ } \\
\text {-ödik }\end{array}$ & -ó/-ő & $-S$ & $\begin{array}{l}\text { koji ima sposobnost da } \\
\text { postepeno postane beo }\end{array}$ \\
\hline fehérellö & -1 & \multicolumn{2}{|l|}{-ó/-ő } & koji se beli \\
\hline fehéres & \multicolumn{3}{|l|}{$-S$} & beličast \\
\hline fehéresedö & $-S$ & $\begin{array}{l}\text {-odik/ } \\
\text {-edik/ } \\
\text {-ödik }\end{array}$ & -ó/-ő & postepeno postaje beličast \\
\hline fehéresitett & $-S$ & -ít & $\mathrm{t} / \mathrm{tt}$ & izbeljivan \\
\hline fehéresitö & $-\mathrm{S}$ & -ít & -ó/-ő & izbeljivač \\
\hline fehéreske & $-S$ & \multicolumn{2}{|c|}{-ka/-ke } & beličast (deminutiv) \\
\hline fehéreslö & $-S$ & $-1(\mathrm{ik})$ & -ó/-ő & beličasti se \\
\hline fehéretlen & \multicolumn{3}{|c|}{-atlan/-etlen } & $\begin{array}{l}\text { bezbelo (nedostatak bele } \\
\text { boje) }\end{array}$ \\
\hline
\end{tabular}




\begin{tabular}{|c|c|c|c|c|}
\hline fehérezett & $-\mathrm{z}$ & \multicolumn{2}{|l|}{$-\mathrm{t} /-\mathrm{tt}$} & beljivan \\
\hline fehérezö & $-\mathrm{z}$ & \multicolumn{2}{|l|}{-ó/-ö } & izbeljivački \\
\hline fehérezös & $-\mathrm{z}$ & -ó/-ö & $-\mathrm{s}$ & izbeljivački \\
\hline fehéritendö & -ít & \multicolumn{2}{|c|}{-andó/-endő } & koji treba da se izbeli \\
\hline fehérítetlen & -ít & \multicolumn{2}{|c|}{-atlan/-etlen } & neizbeljivan \\
\hline fehéritett & -ít & \multicolumn{2}{|l|}{$-\mathrm{t} /-\mathrm{tt}$} & izbeljivan \\
\hline fehérithetetlen & -ít & $\begin{array}{l}\text {-ható/ } \\
\text {-hető }\end{array}$ & $\begin{array}{l}\text {-tlan/ } \\
\text {-tlen }\end{array}$ & nemogućnost izbeljivanja \\
\hline fehérithetö & -ít & \multicolumn{2}{|c|}{-ható/-hető } & koji se može izbeljivati \\
\hline fehéritlen & -ít & \multicolumn{2}{|c|}{-tlan/-tlen } & neizbeljivan \\
\hline fehéritó & -ít & \multicolumn{2}{|l|}{-ó/-ő } & izbeljujući \\
\hline fehéritös & -ít & -ó/-ö & $-\mathrm{s}$ & $\begin{array}{l}\text { izbeljujući, koji služi za } \\
\text { izbeljivanje }\end{array}$ \\
\hline fehérkedö & \multirow{2}{*}{\multicolumn{3}{|c|}{ 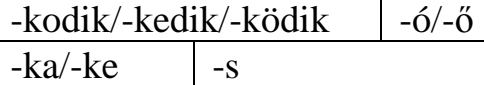 }} & koji se beli \\
\hline fehérkés & & & & beličast \\
\hline fehérlö & $-1(\mathrm{ik})$ & \multicolumn{2}{|l|}{-ó/-ő } & koji se beli \\
\hline fehérlös & $-1(\mathrm{ik})$ & -ó/-ö & $-\mathrm{s}$ & koji se beli \\
\hline fehérré & \multicolumn{3}{|l|}{-vá/-vé } & pretvara u belo, čini belim \\
\hline fehérséges & -ság/-ség & \multicolumn{2}{|l|}{$-\mathrm{s}$} & $\begin{array}{l}\text { prebelo (analogija prema } \\
\text { szépséges - prelepo) }\end{array}$ \\
\hline fehérségi & -ság/-ség & \multicolumn{2}{|l|}{$-\mathrm{i}$} & belosni (stepen belosti) \\
\hline fehérségü & -ság/-ség & \multicolumn{2}{|l|}{-úl-ü } & belosni \\
\hline fehértelen & \multicolumn{3}{|c|}{-talan/-telen } & $\begin{array}{l}\text { bezbelo (nedostatak bele } \\
\text { boje) }\end{array}$ \\
\hline fehérü & \multicolumn{3}{|l|}{-ú/-ú } & belosni \\
\hline fehérülö & -ul/-ül & \multicolumn{2}{|l|}{$-o ́-$-ó } & početi se beleti \\
\hline fehérült & -ul/-ül & \multicolumn{2}{|l|}{$-\mathrm{t}$} & pobeleo \\
\hline
\end{tabular}

Főnévképzés

\begin{tabular}{|c|c|c|c|c|}
\hline Szó & \multicolumn{3}{|c|}{ képzők } & szerb fordítás \\
\hline Fehér $^{3}$ & \multirow{2}{*}{\multicolumn{3}{|c|}{-cska/-cske }} & Feher kao prezime \\
\hline fehérecske & & & & $\begin{array}{l}\text { belka, belica (deminutiv), } \\
\text { malo i belo }\end{array}$ \\
\hline fehéredés & & -ödik & -ás/-és & beljenje \\
\hline fehéres & \multicolumn{3}{|c|}{$-\mathrm{s}$} & beličasti \\
\hline fehéresedés & $-\mathrm{s}$ & $\begin{array}{l}\text {-odik/ } \\
\text {-edik/-ödik }\end{array}$ & -ás/-és & $\begin{array}{l}\text { proces postajanja } \\
\text { beličastim }\end{array}$ \\
\hline fehéresités & $-\mathrm{s}$ & -ít & -ás/-és & izbeljivanje \\
\hline fehéresség & $-\mathrm{s}$ & -ság/-ség & & beličasto svojstvo \\
\hline
\end{tabular}

\footnotetext{
${ }^{3}$ Mint tulajdonnév.
} 


\begin{tabular}{|c|c|c|c|c|}
\hline fehérezés & $-\mathrm{z}$ & \multicolumn{2}{|l|}{-ás/-és } & $\begin{array}{l}\text { 1. ispijanje belog vina } 2 \text {. } \\
\text { insistiranje na beloj rasi }\end{array}$ \\
\hline fehérezö & $-\mathrm{z}$ & \multicolumn{2}{|l|}{-ó/-ö } & $\begin{array}{l}\text { preterano insistiranje na } \\
\text { belom (bilo da je rasa ili } \\
\text { nešto drugo u pitanju) }\end{array}$ \\
\hline fehérités & -ít & \multicolumn{2}{|l|}{-ás/-és } & beljenje \\
\hline fehéritgetés & -ít & -gat/-get & -ás/-és & izbeljivanje \\
\hline fehéritó & -ít & \multicolumn{2}{|l|}{-0 -ólő } & izbeljivač \\
\hline fehérje & \multicolumn{3}{|l|}{$-\mathrm{ja} /-\mathrm{je}$} & $\begin{array}{l}\text { 1. belančevina } 2 \text {. belina } 3 \text {. } \\
\text { beonjača } 4 \text {. belance } 5.10 \text {, } \\
\text { mast }\end{array}$ \\
\hline fehérkedés & \multicolumn{2}{|c|}{-kodik/-kedik/-ködik } & -ás/-és & $\begin{array}{l}\text { preterano naglašavanje } \\
\text { belog, rasizam }\end{array}$ \\
\hline fehérkedö & \multicolumn{2}{|c|}{-kodik/-kedik/-ködik } & -ó/-ö & $\begin{array}{l}\text { razmetanje svojom } \\
\text { belinom, rasizam }\end{array}$ \\
\hline fehérként & \multicolumn{3}{|l|}{-ként } & kao belo, kao belac \\
\hline fehérlés & $-1(\mathrm{ik})$ & \multicolumn{2}{|l|}{-ás/-és } & isticanje belinom \\
\hline fehérség & \multicolumn{3}{|l|}{-ság/-ség } & belilo, belost \\
\hline fehértelenítés & $\begin{array}{l}\text {-talan/ } \\
\text {-telen }\end{array}$ & -ít & -ás/-és & obezbeljivanje \\
\hline fehérülés & -ul/-ül & \multirow{2}{*}{\multicolumn{2}{|c|}{-ás/-és }} & $\begin{array}{l}\text { prelazak u belo, postajanje } \\
\text { belim }\end{array}$ \\
\hline fehérzet & -zat/-zet & & & belilo \\
\hline
\end{tabular}

Igeképzés

\begin{tabular}{|l|l|l|l|}
\hline szó & \multicolumn{2}{|l|}{ képzök } & szerb fordítás \\
\hline fehéredik & \multicolumn{2}{|l|}{-odik/-edik/-ödik } & postajati beo \\
\hline fehérel $($ l $i k)$ & -1 & -l(ik) & beleti se \\
\hline fehéresedik & - -s & -odik/-edik/-ödik & izbeljivati se postepeno \\
\hline fehérez(ik) & -z(ik) & $\begin{array}{l}\text { nazivati belcem ili belim, } \\
\text { bojiti u belo }\end{array}$ \\
\hline fehérít & -ít & $\begin{array}{l}\text { beliti, izbeljivati, bojiti u } \\
\text { belo }\end{array}$ \\
\hline fehérítget & -ít & -gat/-get & izbeljivati \\
\hline fehéríttet & -ít & -tat/-tet & $\begin{array}{l}\text { uticati, činiti da se nešto } \\
\text { izbeli (kauzativ) }\end{array}$ \\
\hline fehérkedik & \multicolumn{2}{|l|}{-kodik/-kedik/-ködik } & $\begin{array}{l}\text { beleti se, razmetati se } \\
\text { svojom belom bojom }\end{array}$ \\
\hline fehérlik & \multicolumn{2}{|l|}{-lik } & beleti se \\
\hline fehérül & \multicolumn{2}{|l|}{-ul/-ül } & izbeljuje se, postaje belo \\
\hline
\end{tabular}


Határozószó-képzés

\begin{tabular}{|c|c|c|c|c|}
\hline Szó & \multicolumn{3}{|l|}{ képzők } & szerb fordítás \\
\hline fehérebben & \multicolumn{2}{|l|}{$-b b$} & -an/-en & belje \\
\hline fehéredöen & $\begin{array}{l}\text {-odik/ } \\
\text {-edik/ } \\
\text {-ödik }\end{array}$ & -ó/-ô & -an/-en & $\begin{array}{l}\text { na način na koji nešto } \\
\text { postaje belo }\end{array}$ \\
\hline fehérelve & -1 & \multicolumn{2}{|l|}{-va/-ve } & beleći se, izbeljujući \\
\hline fehéren & \multicolumn{3}{|l|}{-an/-en } & belo \\
\hline fehéresebben & $-\mathrm{s}$ & $-b b$ & -an/-en & beličastije \\
\hline fehéresedve & $-\mathrm{s}$ & $\begin{array}{l}\text {-odik/ } \\
\text {-edik/-ödik }\end{array}$ & -va/-ve & postajući belim \\
\hline fehéresen & $-\mathrm{s}$ & \multicolumn{2}{|l|}{-an/-en } & beličasto \\
\hline fehéresitve & $-s$ & -ít & -va/-ve & beljeno \\
\hline fehérezve & $-\mathrm{Z}$ & \multicolumn{2}{|l|}{-va/-ve } & beleći \\
\hline fehérítetlenül & -ít & $\begin{array}{l}\text {-atlan/ } \\
\text {-etlen } \\
\end{array}$ & -ul/-ül & nebeljeno, neizbeljivano \\
\hline fehéritöen & -ít & -ó/-ő & -an/-en & na izbeljujući način \\
\hline fehéritve & -ít & \multicolumn{2}{|l|}{-va/-ve } & izbeljujući, izbeljeno \\
\hline fehérkésen & $-\mathrm{ka} /-\mathrm{ke}$ & $-\mathrm{s}$ & -an/-en & $\begin{array}{l}\text { beličasto, na beličasti } \\
\text { način }\end{array}$ \\
\hline fehérlöen & -1 & -ó/-ő & -an/-en & beleći se \\
\hline fehérségesen & -ság/-ség & $-\mathrm{S}$ & -an/-en & na preterano beo način \\
\hline fehértelenül & $\begin{array}{l}\text {-talan/ } \\
\text {-telen }\end{array}$ & \multirow{2}{*}{\multicolumn{2}{|c|}{-ul/-ül }} & bezbelosno \\
\hline fehérül & -ul/-ül & & & belo \\
\hline
\end{tabular}

\section{A 'fehér' színt tartalmazó frazeológiai egységek}

A fehér/beo alapszót tartalmazó frazémák létrejöttét többnyire a színnév szemantikája és szimbolikája motiválta. A 'fehér', amint fentebb láttuk, leginkább pozitív jelentéssel bír, a fekete ellenpárját képezi. Mintegy mennyei világosságot állít szembe az alvilági sötétséggel. A ‘fehér' zömmel a jó megtestesítője, a tisztasággal, ártatlansággal, nyugalommal, boldogsággal, fiatalsággal, élettel hozható kapcsolatba. Ugyanakkor azonban a haladásellenes politikai erőket, a megadást, a gyengeséget, valamint a félelmet, betegséget, öregséget és a halált is szimbolizálhatja. Vlajković és Stamenković (2013) A Language and Ideology könyvre hivatkozva megállapítja, hogy a 'fehér' és a 'fekete' ellentéte az emberi tapasztalatban és abban a tudásban rejlik, miszerint a tiszta, bontatlan napfény 
fehér színü, s ha nincs napfény, akkor azt feketeként érzékeljük. Tehát a két szín ellentéte a konceptualizáción alapszik, a 'fehér' és 'fekete’ önmagában se nem jó, se nem rossz, hanem az ember ilyen jelentéstöbbletet tulajdonít nekik. A különböző értékek az ikonográfiai referenciakeretben az emberi tapasztalat alapján létrejött alapértékeket reflektáló képekkel társulnak mélyebben az élet, illetve a halál dichotómiájával (Vlajković-Stamenković 2013: 550).

A 'fehér' alapszóval a magyarban és a szerbben megközelítőleg azonos számú frazeológiai egységet találtam, ${ }^{4}$ de teljes ekvivalenciáról már ritkábban beszélhetünk. Ami első pillanatra szembetünő volt, az arra utal, hogy a szerb szólások, még akkor is, ha lexikai összetételük a magyar példákéval teljes mértékben megegyezik, nem általánosságban vonatkoztathatóak a tárgyakra, jelenségekre, hanem konkrétan az embert jellemzik. Itt most csak egy példát említek a fehér, mint a hó magyar hasonlat kapcsolatba hozható például a kenyérrel, a bőrrel, a frissen meszelt fallal, míg a beo kao sneg csak emberi testrésszel (haj, szakáll, fog).

Az említett példán kívül létezik még néhány szóláshasonlat mindkét nyelvben, ezek leginkább valaminek a nagyon világos voltára utalnak. Amennyiben világos arcbőrt jelölnek, az lehet kívánatos (különösen a múlt századbeli szépségideált szemmel tartva), de közvetve utalhat az illető erkölcsére vagy testi és lelki állapotára is, arra ugyanis, hogy beteges vagy rémült.

\begin{tabular}{lll} 
magyar hasonlatok & jelentésük & szerb ekvivalensük $^{\mathbf{5}}$ \\
\hline fehér, mint a fal & nagyon sápadt arcú & beo kao kreč \\
\hline fehér, mint a galamb & $\begin{array}{l}\text { teljesen ösz, galambösz a } \\
\text { haja }\end{array}$ & golubije bela \\
\hline $\begin{array}{l}\text { fehér valami, mint a } \\
\text { gyolcs }\end{array}$ & $\begin{array}{l}\text { vmi (pl. vászon) tiszta fehér, } \\
\text { hófehér }\end{array}$ & beo poput platna \\
\hline $\begin{array}{l}\text { fehér valami, mint a } \\
\text { hattyú }\end{array}$ & $\begin{array}{l}\text { női testrész ragyogóan szép } \\
\text { fehér színü }\end{array}$ & labuđe beli (vrat) \\
\hline
\end{tabular}

\footnotetext{
${ }^{4}$ A magyar korpuszt a Bárdosi, Forgács, O Nagy, Litovkina és az ÉKSz., a szerbet pedig Matešić, Otašević és a RMS-böl gyüjtött példák képezik.

${ }^{5}$ Amennyiben a szerb megfelelők nem dőlt betűkkel vannak feltüntetve, ez azt jelenti, hogy a szerb szótárakban nem tartják öket számon, de a beszélt nyelvben előfordulnak. Három magyar hasonlatnak viszont egyáltalán nincs ekvivalense a szerbben.
} 
fehér, mint a

nagyon fehér bőrü személy

hipóreklám

\begin{tabular}{lll}
\hline $\begin{array}{l}\text { fehér, mint a hól } \\
\text { fehérebb a hónál }\end{array}$ & $\begin{array}{l}\text { nagyon szép fehér (pl. } \\
\text { kenyér, bör, frissen meszelt } \\
\text { fal) }\end{array}$ & beo kao sneg \\
\hline fehér, mint a kísértet & $\begin{array}{l}\text { ijesztően megviselt, sápadt } \\
\text { és lesoványodott (személy) }\end{array}$ & $\begin{array}{l}\text { beo/ providan kao } \\
\text { duh }\end{array}$ \\
\hline fehér, mint a liliom & $\begin{array}{l}\text { ártatlan, erkölcsileg tiszta } \\
\text { személy }\end{array}$ & - \\
\hline fehér, mint a patyolat & $\begin{array}{l}\text { 1. (különösen bör) finom, } \\
\text { sima, fehér 2. vakító fehér, }\end{array}$ \\
& hófehér \\
\hline fehér, mint a tej & nagyon fehér börü személy & belo kao mleko \\
\hline fehér, mint az & hamvasan tiszta, fehér (nöi & bele, providne puti \\
alabástrom & arc, bör) & \\
\hline
\end{tabular}

beo kao inje jako, vrlo beo (kosa, brada) ${ }^{6}$ dérfehér

beo kao kreda sasvim bled $^{7}$ krétafehér

A 'fehér' az erkölcsi TISZTASÁG, BECSÜLET, ÁRTATLANSÁG jelképe: fehér, mint a liliom, fehérek közt európai, s ha valaki fehérre mos valakit vagy mossa magát, szintén ennek az erkölcsösségnek a látszatát szeretné kelteni. Amennyiben azonban mégsem becsületes üzletről van szó, hanem gazdasági bünözésről, akkor a fehér- előtagú összetétel elkövetőjének sajátos, munkájából adódó öltözetére utal: fehérgalléros bünözés, fehérgalléros bünözö (fehér inget viselö tiszt(ség)viselő). Az utóbbinak a szerbben részben a biti s belim okovratnikom szólás felel meg, 'olyan magas poszton levő személy, aki ártatlannak tetteti magát, holott nem az, de nem lehet rábizonyítani tettét'.

Itt kell megemlíteni a fehér vicc szókapcsolatot is a magyarban, amely az ártatlan, illemet nem sértő viccre vonatkozik, olyanra, amelyet nők vagy gyerekek előtt is el lehet mondani. Hasonló konnotációjú a fehér irodalom jelzős szerkezet is 'a társadalmi problémákat nem érintő, a nemiség kérdéseit kerülő, főleg serdülő lányoknak szánt irodalom’.

\footnotetext{
${ }^{6}$ Nagyon, igen fehér (haj, szakáll).

${ }^{7}$ Teljesen sápadt.
} 
A ‘fehér' a legfényesebb és legvilágosabb szín, a szerbben a beo melléknév, amint már fentebb említettem, eredetileg a fényességet és ragyogást is jelentette, ezért a 'nap' főnévvel alkot jelzős szerkezetet, míg a magyar ekvivalensekben a ‘fény', és a 'világosság' (mint a fehér szín konceptuális részei) szerepelnek: beli dan (= fehér nap) - fényes nap, izneti na beli dan (= fehér napra visz ki) napfényre/nyilvánosságra hoz, ne videti ni bela dana (= nem lát fehér napot sem) - nem lát napvilágot, u po/usred bela dana (= fehér nappal /nap közepén) fényes/világos nappal.

A fehér a TÖKÉLYt, az ESZMÉNYt a FÉRFIIDEÁLt is kifejezheti: a herceg a fehér lovon a szerb frazeológiai szótárban a princ na belom konju (amely egyébként az élőnyelvben nagyon gyakori szólás) helyett, csak a princ iz bajke 'mesebeli herceg' változat van meg.

Néhány TERMÉSZETI JELENSÉGet, illetve a belőlük fakadó hiedelmeket is megőrizték az állandósult szókapcsolatok, a szólások. Ilyenek a fehér éjszakabele noći ('sarkvidék közelében bizonyos ideig szinte nappali fénnyel járó éjszaka'), fehér karácsony ('olyan karácsony, amikor hó borítja a tájat'), ezzel rokon szólás a szerbben a doći/osvanuti na belom konju ('hóval érkezik' és nem kimondottan a karácsonyra vonatkozik), fekete karácsony - fehér húsvét ('népi megfigyelés: ha karácsonykor nincs hó és olvad, húsvétkor hideg lesz és havazni fog').

A vizet mint energiaforrást a magyar korpuszban két szerkezet is jelöli: a fehér arany és a fehér szén. Mindkettő a tiszta konceptualizációja is egyben. A szerbben is megtaláljuk a két jelzős szerkezetet, de míg a beli ugalj ugyanazt fejezi ki, mint a magyar, a belo zlato az arany fehér fémmel készült ötvözetére vonatkozik.

A 'fehér' egyfajta hiányt, ürt is jelenthet, s egyben a rossz, a negatív konnotációját is tartalmazza. Így a fehér folt 'ismeretlen, még fel nem kutatott földrajzi vagy tudományos terület' értelemben, a szerb bela kuga (= fehér pestis) az újszülöttek hiányát, a bela udovica (= fehér özvegy - nö) a férj hiányát, a beli udovac (= fehér özvegy - férfi) a feleség hiányát, a gledati belo (= fehéren néz) az értelem hiányát, a ne pomaljati/pomoliti ni bela zuba (= nem mutatja a foga 
fehérjét sem) a beszéd hiányát illusztrálja. Létezik a magyarban is egy szólás, amely a fehér fogakat említi, de egészen más értelemben használjuk: kimutatja a foga fehérjét annyit jelent, hogy 'megmutatja eddig leplezett, gonosz szándékát'

Ha valami nagyon elüt a többitől, ha rendkívüli ritkaságot, vagy másságot képvisel, akkor azt mindkét nyelvben a fehér holló - bela vrana ekvivalens szólással illetik.

Az őszülő, fehér haj, szakáll az emberi élet alkonyának, az ÖREGSÉGnek a jele. A magyarban inkább a bőr színét hasonlítják valamely fehér jelenséghez, kimondottan az ősz hajra csak a fehér, mint a galamb hasonlat vonatkozik. A szerbben ennél sokkal több szólás fordul elö ilyen funkcióban: beo kao inje (= fehér, mint a dér, 'nagyon fehér/ősz haj'), bela brada (= fehér szakáll, 'nagyon idős férfi'), bela glava (= fehér fej, két jelentése is van 1. 'ősz fej' 2. 'okos, tapasztalt személy'), bele plesti/plesti bele vlasi (= fehéret/fehér haját fonja, “ősz hajú nő, megvénült hajadon'), s nem utolsósorban a bele godine (= fehér évek, 'öregkor'). De a halállal is kapcsoltba hozza a szerb frazeológia a fehér színt: bela smrt (= fehér halál) - fagyhalál. A pestis halálos betegséggel alkotott jelzős szerkezetben bela kuga (= fehér pestis) a szándékos elvetélést és a gyermekvállalásról való lemondást, szélesebb kontextusban pedig az alacsony szülési/születési arányt, illetve a népszaporulat negatív arányszámát jelöli.

Létezik még néhány azonos szólás a két nyelvben, amelyek bizonyos jellegzetes rendeltetésü tárgyakra vonatkoznak. Így a fehér zászló - bela zastava, kitüzi a fehér zászlót - istaći belu zastavu, a megadást, a fegyverletételt, a kapitulációt, a küzdelemtől való elállást, a célokról, elvekről való lemondást, a tárgyalás kényszerüségének elfogadását $\mathrm{s}$ egyben a gyengeség elismerését is jelenti. Hasonló, de ennél sokkal pozitívabb konnotációjú a felszáll a fehér füst vhol szólásnak, amely valamely régen várt egyezség, kompromisszumos döntés, engedély megszületéséröl tanúskodik.

A fehér könyv - bela knjiga diplomáciai okmányok gyüjteményét képezi, amelyet valamely kormány álláspontjának, eljárásának igazolására tesz közzé, 
illetve olyan kiadvány, amelyben egy érdekcsoport (többnyire politikai párt) kifejti saját nézeteit.

A fehér pénznek a szerbben csak formai ekvivalense a beli novcilbele pare szókapcsolat. Míg a magyarban jelenthet 'ezüstpénzt' vagy pedig a 'hátlapján fehéren hagyott bankjegyet', addig a szerbben a megtakarított pénzre vonatkozik. ${ }^{8}$

$\mathrm{S}$ míg a beli hleb 'fehér kenyér' frazéma a jómódra utal, addig a biti na belom hlebu szólásnak egészen más jelentése van. Ugyanis egykor azt a rabot, akit halálra ítéltek, az utolsó napon megkülönböztetett bánásmódban részesítették, így a kivégzés elött fehér kenyeret kapott enni. Az említett szerkezet ezt a hagyományt örizte meg.

Még egy gyakori szószerkezet létezik a szerbben a 'fehér' színnel, amely több szólásban is tetten érhető. Ez a beli svet amely szó szerint 'fehér világot' jelent, de valójában messzi, idegen, ismeretlen tájakat jelöl. Ilyenek még a bežati/ići/otići preko bela sveta (= elmenekül/elmegy a fehér világon át) 'elmegy otthonról messzire, idegen országba', bežati/pobeći/poći/otisnuti se $u$ beli svet (= elmenekül/elindul/elrugaszkodik a fehér világba) 'otthagyja otthonát a jobb megélhetés érdekében', obijati beli svet (= koptatja/tapossa a fehér világot) 'ismeretlen/idegen országokban ide-oda vetődik'. Mindezekre a magyarban csak azt szoktuk mondani, hogy 'a nagyvilág', 'világgá megy', 'járja a nagyvilágot'.

A teniszt mindkét érintett nyelvben fehér sportnak nevezik, legföképp abból a képből kiindulva, hogy régen csak fehér ruhában játszották.

Léteznek tréfás szólások is mindkét nyelvben, bár teljesen más kontextusban használjuk őket, és más a lexikai szerkezetük is. A magyarban, amikor valaki valamilyen okból kifolyólag hány, a telefon- és a WC kagyló közötti homonimitás jut kifejezésre a belebeszél/beleszól a nagy fehér mikrofonba, telefonál a nagy fehér kagylóba szólásokban.

A szerbben a beli konac, szószerint 'fehér cérna' ironikusan pálinkát jelent. ${ }^{8}$ Csak érdekességként említjük, hogy a takarít ige szinonimája a tisztít, tehát a megtakarított pénz
tiszta, a legtisztább, legfényesebb szín pedig a fehér. 


\section{Összetételek, szószerkezetek}

Mindkét nyelvben vannak olyan kifejezések, amelyek nem számítanak frazémának, de gyakran előforduló összetételeket vagy állandósult szókapcsolatokat képeznek. Jelentésük olykor - akár a szólások esetében is - nem azonos alkotóelemeik jelentésének összegével, még akkor sem, ha szószerinti fordítással adhatjuk vissza öket a célnyelvben.

Ilyen pl. a magyarban a fehércseléd vagy fehérnép szókapcsolat, amelyek a nőkre, asszonyokra vonatkoznak. Valami hasonló létezik a szerbben, ez a belo roblje 'fehér rabok', amely szintén női személyeket jelent, de nem semleges értelmü, hanem a nőcsempészet áldozataira vonatkozik, olyan nőkre, akiket rabszolgakereskedelem vagy csalás által egykor a török háremekbe, ma pedig nyilvánosházakba hurcolnak.

Itt most csak néhány összetételt említek, a dolgozat második mellékletében viszont (a teljesség igénye nélkül) felsorolom a magyarban előforduló kollokációs egységeket, szerb fordításukkal.

fehéranyag ${ }^{9}$ ipar

fehérállomány ${ }^{10}$ bonc

fehérbádog ${ }^{11}$ ipar

fehérbor

fehérfolyás ${ }^{2}$ orv

fehérgalléros átv

fehérgárdista tört

fehérjelánc vegy

fehérjetakarmány mezőg

fehérjetartalom vegy

fehérjevizelés orv čista supstanca

svetliji deo mozga, bela moždina

beli lim

belo vino

belo pranje

službenik ili funkcioner

Belogardejac

lanac belančevina

stočna hrana bogata belančevinama

sadržaj belančevina

izlučivanje belančevina putem mokraće

\footnotetext{
${ }^{9}$ Edények, hintőpor készítéséhez használt tiszta anyag.

${ }^{10}$ Az agynak belső, világosabb színü része.

${ }^{11}$ Horganyozott, rozsdaálló bádog.

12 Fehér váladék a hüvelyből.
} 


$\begin{array}{ll}\text { fehérlepke áll } & \text { beli leptir } \\ \text { fehérmáj bonc } & \text { bela džigerica } \\ \text { fehérnemü } & \text { beli veš } \\ \text { fehérnép } & \text { žene } \\ \text { fehérorosz } & \text { Belorus } \\ \text { fehérpecsenye konyha } & \text { bela vešalica } \\ \text { fehérrépa növ } & \text { bela rotkva } \\ \text { fehérszemély } & \text { žena } \\ \text { fehérterror tört } & \text { beli teror } \\ \text { fehérvarrónö } & \text { krojačica koja šije beli veš i posteljinu } \\ \text { fehérvasárnap } & \text { prva nedelja posle Uskrsa } \\ \text { fehérvérsejt orv } & \text { bela krvna zrnca } \\ \text { fehérvérü orv } & \text { belokrvan } \\ \text { fehérvérüség orv } & \text { belokrvnost }\end{array}$

A fentiekből kiderül, hogy a szerb nyelvü ekvivalensek nagy részében is jelen van a 'fehér' mint színnév. De nem mindig van így, az alábbi felsorolásban szerb növény- és állattani terminusok fordulnak elö, itt már azt láthatjuk, hogy a megfeleltetéskor egyetlen egyszer fordul csak elő a magyarban a fehér:

$\begin{array}{ll}\text { belobor } & \text { fenyő } \\ \text { belocvat } & \text { sárga nárcisz, húsvétvirág } \\ \text { belodun } & \text { nyúlszapúka, nyúlhere } \\ \text { beloglavica } & \text { dárdahere } \\ \text { belogorica } & \text { lombhullató fa } \\ \text { belograb } & \text { gyertyánfa } \\ \text { belogrud } & \text { fehérmellủ } \\ \text { belojka } & \text { virágos kender } \\ \text { belopandara } & \text { kökényszilva } \\ \text { belorepka } & \text { vörös szárnyú koncér/ keskeny levelü } \\ & \text { ökörfarkkóró } \\ \text { belošljiva } & \text { kökényszilva }\end{array}$


belouška

belovina vízisikló

tölgyfa (anyag)

Említsük még meg a bela tehnika szerkezetet, amely a háztartási gépekre vonatkozik.

\section{Összegzés}

Függetlenül attól, hogy a magyar és a szerb nyelv genetikailag és tipológiailag is különböző nyelvcsoportba tartozik, a 'fehér' kontrasztív összevetése során arra a következtetésre jutottunk, hogy az elemzés tárgyát képező nyelvek között az érintett fogalomkör kapcsán nagyfokú hasonlóság, sőt azonosság is kimutatható. Az ekvivalencia több síkon is tetten érhető, így a fogalom szemantikai síkján, a szimbólumrendszerén, a frazeológia terén is jelentkezik. Mindez a két nép és kultúra évszázadokon keresztül való egymás mellett és együttélésével magyarázható. Azonban eltéréseket is tapasztalhatunk, amelyek viszont legnagyobb mértékben a nyelvrendszerbeli különbségekből erednek. Lévén a magyar agglutináló, a szerb pedig flektáló nyelv, az eltérések legfőképpen a két lexéma származékszavai, valamint az árnyalatok megnevezése között mutatható ki. A magyar nyelv szintetikus kifejezésmódja itt kifejezetten szemben áll a szerb analitikus megfogalmazásokkal.

1. számú melléklet: A fehér szín árnyalatai ${ }^{13}$

Tiszta színek

\begin{tabular}{|l|l|l|l|}
\hline fehér & $\begin{array}{l}\text { \#FFFFFF, RGB: } \\
\text { 255 255 255, H: - }\end{array}$ & white & beo/bela/belo \\
\hline álomfehér & $\begin{array}{l}\text { \#FFFFFF, RGB: } 255 \\
255 \text { 255, H: - }\end{array}$ & dream-white & beo poput sna \\
\hline alpinfehér & $\begin{array}{l}\text { \#FFFFFF, RGB: 255 } \\
\text { 255 255, H: - }\end{array}$ & Alpine-white & alpsko bela \\
\hline angyalfehér & $\begin{array}{l}\text { \#FFFFFF, RGB: } 255 \\
\text { 255 255, H: - }\end{array}$ & angel white & anđeosko bela \\
\hline
\end{tabular}

${ }^{13}$ Itt olyan árnyalatnevek is szerepelnek, amelyek nem tartalmazzák a fehér lexémát, de ettől függetlenül a fehér színtartományába tartoznak. 


\begin{tabular}{|c|c|c|c|}
\hline baritfehér & $\begin{array}{l}\text { \#FFFFFF, RGB: } 255 \\
255 \text { 255, H: - }\end{array}$ & baryte-white & baritno bela \\
\hline csipkefehér & $\begin{array}{l}\text { \#FFFFFF, RGB: } 255 \\
255 \text { 255, H: - }\end{array}$ & lace white & čipka-bela \\
\hline dérfehér & $\begin{array}{l}\text { \#FFFFFF, RGB: } 255 \\
255 \text { 255, H: - }\end{array}$ & frost white & beo kao inje \\
\hline fátyolszín & $\begin{array}{l}\text { \#FFFFFF, RGB: } 255 \\
255 \text { 255, H: - }\end{array}$ & $\begin{array}{l}\text { white veil } \\
\text { color }\end{array}$ & boja belog vela \\
\hline felhöfehér & $\begin{array}{l}\text { \#FFFFFF, RGB: } 255 \\
255 \text { 255, H: - }\end{array}$ & cloud white & oblak-bela \\
\hline galambfehér & $\begin{array}{l}\text { \#FFFFFF, RGB: } 255 \\
255 \text { 255, H: - }\end{array}$ & dove white & golubije bela \\
\hline gleccserfehér & $\begin{array}{l}\text { \#FFFFFF, RGB: } 255 \\
255 \text { 255, H: - }\end{array}$ & glacier white & glečer-bela \\
\hline gyapotfehér & $\begin{array}{l}\text { \#FFFFFF, RGB: } 255 \\
255 \text { 255, H: - }\end{array}$ & cotton-white & $\begin{array}{l}\text { pamuk-bela, } \\
\text { pamučno bela }\end{array}$ \\
\hline gyolcsfehér & $\begin{array}{l}\text { \#FFFFFF, RGB: } 255 \\
255 \text { 255, H: - }\end{array}$ & $\begin{array}{l}\text { fine linen } \\
\text { white }\end{array}$ & platno-bela \\
\hline gyöngyvirágfehér & $\begin{array}{l}\text { \#FFFFFF, RGB: } 255 \\
255 \text { 255, H: - }\end{array}$ & $\begin{array}{l}\text { lily of the } \\
\text { valley white }\end{array}$ & đurđevak-bela \\
\hline habfehér & $\begin{array}{l}\text { \#FFFFFF, RGB: } 255 \\
255 \text { 255, H: - }\end{array}$ & foam white & bela poput pene \\
\hline harmatszín & $\begin{array}{l}\text { \#FFFFFF, RGB: } 255 \\
255 \text { 255, H: - }\end{array}$ & dew color & boja rose \\
\hline hattyúfehér & $\begin{array}{l}\text { \#FFFFFF, RGB: } 255 \\
255 \text { 255, H: - }\end{array}$ & $\begin{array}{l}\text { swan white } \\
\text { color }\end{array}$ & $\begin{array}{l}\text { labude bela, } \\
\text { boja belog } \\
\text { labuda }\end{array}$ \\
\hline hermelinfehér & $\begin{array}{l}\text { \#FFFFFF, RGB: } 255 \\
255 \text { 255, H: - }\end{array}$ & ermine white & hermelin-bela \\
\hline Himalája-fehér & $\begin{array}{l}\text { \#FFFFFF, RGB: } 255 \\
255 \text { 255, H: - }\end{array}$ & $\begin{array}{l}\text { Himalaya } \\
\text { white }\end{array}$ & himalajskobela \\
\hline hófehér & $\begin{array}{l}\text { \#FFFFFF, RGB: } 255 \\
255 \text { 255, H: - }\end{array}$ & snow white & snežnobela \\
\hline jázminfehér & $\begin{array}{l}\text { \#FFFFFF, RGB: } 255 \\
255 \text { 255, H: - }\end{array}$ & $\begin{array}{l}\text { jasmine } \\
\text { white }\end{array}$ & jasmin-bela \\
\hline kókuszfehér & $\begin{array}{l}\text { \#FFFFFF, RGB: } 255 \\
255 \text { 255, H: - }\end{array}$ & $\begin{array}{l}\text { coconut } \\
\text { white }\end{array}$ & kokos-bela \\
\hline krétafehér & $\begin{array}{l}\text { \#FFFFFF, RGB: } 255 \\
255 \text { 255, H: - }\end{array}$ & chalk white & bela poput krede \\
\hline liliomfehér & $\begin{array}{l}\text { \#FFFFFF, RGB: } 255 \\
255 \text { 255, H: - }\end{array}$ & lily white & ljiljan-bela \\
\hline margarétafehér & $\begin{array}{l}\text { \#FFFFFF, RGB: } 255 \\
255 \text { 255, H: - }\end{array}$ & daisy white & margareta-bela \\
\hline
\end{tabular}




\begin{tabular}{|l|l|l|l|}
\hline ólomfehér $^{14}$ & $\begin{array}{l}\text { \#FFFFFF, RGB: 255 } \\
\text { 255 255, H: - }\end{array}$ & $\begin{array}{l}\text { lead-, flake- } \\
\text { white }\end{array}$ & olovo-bela \\
\hline orchideafehér & $\begin{array}{l}\text { \#FFFFFF, RGB: 255 } \\
\text { 255 255, H: - }\end{array}$ & orchid white & orhideja-bela \\
\hline sófehér & $\begin{array}{l}\text { \#FFFFFF, RGB: 255 } \\
\text { 255 255, H: - }\end{array}$ & salt white & $\begin{array}{l}\text { so-bela, bela } \\
\text { poput soli }\end{array}$ \\
\hline sziromfehér & $\begin{array}{l}\text { \#FFFFFF, RGB: } 255 \\
\text { 255 255, H: - }\end{array}$ & petal white & bela poput latice \\
\hline titánfehér & $\begin{array}{l}\text { \#FFFFFF, RGB: } 255 \\
\text { 255 255, H: - }\end{array}$ & $\begin{array}{l}\text { titanium } \\
\text { white }\end{array}$ & titan-bela \\
\hline tündérfehér & $\begin{array}{l}\text { \#FFFFFF, RGB: 255 } \\
\text { 255 255, H: - }\end{array}$ & fairy white & bela poput vile \\
\hline
\end{tabular}

Egyéb fehér színárnyalatok

\begin{tabular}{|l|l|l|l|}
\hline magyar & a szín adatai & angol & szerb fordítás \\
\hline alabástromfehér & $\begin{array}{l}\text { \#EFEBE5, RGB: } 239 \\
\text { 235 229, H: 35 }\end{array}$ & $\begin{array}{l}\text { alabaster- } \\
\text { white }\end{array}$ & alabaster-bela \\
\hline bárányfehér & $\begin{array}{l}\text { \#FDF8F3, RGB: } 253 \\
\text { 248 243, H: 30 }\end{array}$ & lamb white & jagnje-bela \\
\hline bécsi fehér & - & Vienna white & bečko bela \\
\hline bodzafehér & $\begin{array}{l}\text { \#F3FAD2, RGB: } 243 \\
\text { 250 210, H: 71 }\end{array}$ & $\begin{array}{l}\text { elderflower } \\
\text { color }\end{array}$ & zova-bela \\
\hline cukorfehér & $\begin{array}{l}\text { \#F8F8E9, RGB: } 248 \\
\text { 248 233, H: - }\end{array}$ & sugar white & šećer-bela \\
\hline elefántcsontfehér & $\begin{array}{l}\text { \#FDF6E4, RGB: } 253 \\
\text { 246 228, H: - }\end{array}$ & ivory color & slonovača-bela \\
\hline falfehér & $\begin{array}{l}\text { \#F9F7F2, RGB: } 249 \\
\text { 247 242, H: - }\end{array}$ & wall white & zid-bela \\
\hline gipszfehér & $\begin{array}{l}\text { \#E6E3D8, RGB: } 230 \\
\text { 227 216, H: - }\end{array}$ & $\begin{array}{l}\text { gypsum } \\
\text { color }\end{array}$ & gips-bela \\
\hline gólyafehér & $\begin{array}{l}\text { \#F2F4E1, RGB: } 242 \\
\text { 244 225, H: 66 }\end{array}$ & stork color & bela poput rode \\
\hline gyapjúfehér & $\begin{array}{l}\text { \#EDE2CA, RGB: } \\
\text { 237 226 202, H: 41 }\end{array}$ & wool white & vunenobela \\
\hline gyémántfehér & $\begin{array}{l}\text { \#F3F8FF, RGB: } 243 \\
\text { 248 255, H: 215 }\end{array}$ & $\begin{array}{l}\text { diamond } \\
\text { white }\end{array}$ & dijamant-bela \\
\hline gyöngyfehér & $\begin{array}{l}\text { \#F3F2E8, RGB: } 243 \\
\text { 242 232, H: 55 }\end{array}$ & pearl white & bisernobela \\
\hline halottfehér & - & dead white & mrtvačkobela \\
\hline
\end{tabular}

14 Névváltozatai között szerepel a: görögfehér, szaturnuszfehér, kremsi fehér, velencei fehér, fedőfehér, perzsafehér, cerussa. 


\begin{tabular}{|c|c|c|c|}
\hline holdezüst & $\begin{array}{l}\text { \#EEEDF8, RGB: } \\
238237 \text { 248, H: } 245\end{array}$ & Moon-silver & $\begin{array}{l}\text { srebrna poput } \\
\text { meseca }\end{array}$ \\
\hline kagylófehér & $\begin{array}{l}\text { \#FAF2EE, RGB: } 250 \\
242 \text { 238, H: } 20\end{array}$ & shell white & školjka-bela \\
\hline klórfehér & $\begin{array}{l}\text { \#F5F3EB, RGB: } 245 \\
243 \text { 235, H: } 48\end{array}$ & $\begin{array}{l}\text { chlorine } \\
\text { white }\end{array}$ & hlor-bela \\
\hline kócsagfehér & $\begin{array}{l}\text { \#FAFFFE, RGB: } 250 \\
255 \text { 254, H: - }\end{array}$ & heron white & čaplja-bela \\
\hline kristályfehér & $\begin{array}{l}\text { \#EBF3FA, RGB: } \\
235243 \text { 250, H:208 }\end{array}$ & crystal white & kristalnobela \\
\hline krizantémfehér & $\begin{array}{l}\text { \#FBFDE9, RGB: } \\
251253 \text { 233, H: } 65\end{array}$ & $\begin{array}{l}\text { chrysanthe- } \\
\text { mum w. }\end{array}$ & hrizantema-bela \\
\hline lárvafehér & $\begin{array}{l}\text { \#F3EACC, RGB: } \\
243234 \text { 204, H: } 45\end{array}$ & larva white & larva-bela \\
\hline lisztfehér & $\begin{array}{l}\text { \#F4F2ED, RGB: } 244 \\
242 \text { 237, H: } 43\end{array}$ & flour color & brašno-bela \\
\hline litoponfehér & $\begin{array}{l}\text { \#F0F0F0, RGB: } 240 \\
240 \text { 240, H: - }\end{array}$ & $\begin{array}{l}\text { lithopone } \\
\text { white }\end{array}$ & litopon-bela \\
\hline magnóliafehér & $\begin{array}{l}\text { \#FBFAFA, RGB: } \\
251250 \text { 250, H: - }\end{array}$ & $\begin{array}{l}\text { magnolia } \\
\text { white }\end{array}$ & magnolija-bela \\
\hline marcipánfehér & $\begin{array}{l}\text { \#F2ECDA, RGB: } \\
242236 \text { 218, H: } 45\end{array}$ & $\begin{array}{l}\text { marcipane } \\
\text { white }\end{array}$ & marcipan-bela \\
\hline márványfehér & $\begin{array}{l}\text { \#F4F4F2, RGB: } 244 \\
244 \text { 242, H: - }\end{array}$ & marble white & mramornobela \\
\hline mészfehér & $\begin{array}{l}\text { \#EEECE4, RGB: } \\
238236 \text { 228, H: - }\end{array}$ & $\begin{array}{l}\text { limestone } \\
\text { white }\end{array}$ & kreč-bela \\
\hline nyárfehér & $\begin{array}{l}\text { \#EBEBE2, RGB: } \\
235235 \text { 226, H: - }\end{array}$ & poplar white & topola-bela \\
\hline ónfehér & $\begin{array}{l}\text { \#FDF2E4, RGB: } 253 \\
242 \text { 228, H: } 34\end{array}$ & $\begin{array}{l}\text { tin glaze } \\
\text { white }\end{array}$ & kalajnobela \\
\hline opálfehér & $\begin{array}{l}\text { \#F7F9FE, RGB: } 247 \\
249 \text { 254, H:223 }\end{array}$ & opal white & opalnobela \\
\hline papírfehér & $\begin{array}{l}\text { \#F4EDE5, RGB: } 244 \\
\text { 237 229, H: } 32\end{array}$ & paper white & papir-bela \\
\hline patyolatfehér & $\begin{array}{l}\text { \#F3FBFF, RGB: } 243 \\
251 \text { 255, H:200 }\end{array}$ & $\begin{array}{l}\text { lawn cambric } \\
\text { white }\end{array}$ & belo poput vela \\
\hline porcelánfehér & $\begin{array}{l}\text { \#FFFDF3, RGB: } 255 \\
253 \text { 243, H: - }\end{array}$ & $\begin{array}{l}\text { porcelain } \\
\text { white }\end{array}$ & porculanskobela \\
\hline sárfehér & $\begin{array}{l}\text { \#EBE7AE, RGB: } \\
235231 \text { 174, H: } 56\end{array}$ & - & blato-bela \\
\hline tejfehér & $\begin{array}{l}\text { \#FCFBF7, RGB: } 252 \\
251 \text { 247, H: } 48\end{array}$ & milky white & $\begin{array}{l}\text { belo poput } \\
\text { mleka }\end{array}$ \\
\hline
\end{tabular}




\begin{tabular}{|l|l|l|l|}
\hline tejfelfehér & $\begin{array}{l}\text { \#F8F8EB, RGB: 248 } \\
\text { 248 235, H: 60 }\end{array}$ & $\begin{array}{l}\text { sour cream } \\
\text { white }\end{array}$ & pavlaka-bela \\
\hline télfehér & $\begin{array}{l}\text { \#ECF7FF, RGB: } 236 \\
\text { 247 255, H:205 }\end{array}$ & winter white & zimsko bela \\
\hline tojáshéjszín & $\begin{array}{l}\text { \#F0EFE4, RGB: } 240 \\
\text { 239 228, H: 55 }\end{array}$ & $\begin{array}{l}\text { egg shell } \\
\text { color }\end{array}$ & $\begin{array}{l}\text { boja ljuske } \\
\text { jajeta }\end{array}$ \\
\hline tollfehér & $\begin{array}{l}\text { \#F7F7F7, RGB: } 247 \\
\text { 247 247, H: - }\end{array}$ & feather white & belo poput pera \\
\hline vászonfehér & $\begin{array}{l}\text { \#FDFFF3, RGB: } 253 \\
\text { 255 243, H: - }\end{array}$ & linen white & platno-bela \\
\hline vattafehér & $\begin{array}{l}\text { \#FEFEF7, RGB: } 254 \\
\text { 254 247, H: - }\end{array}$ & $\begin{array}{l}\text { cotton wool } \\
\text { white }\end{array}$ & vata-bela \\
\hline zsírfehér & $\begin{array}{l}\text { \#FFFAE5, RGB: } 255 \\
\text { 250 229, H: 48 }\end{array}$ & lard white & mast-bela \\
\hline
\end{tabular}

2. számú melléklet: Magyar szóösszetételek, kollokációk és szerb megfelelőik

$\begin{array}{ll}\text { fehéracél } & \text { beli čelik } \\ \text { fehér agyag } & \text { bela glina } \\ \text { fehérállomány } & \text { bela moždina } \\ \text { fehér angyal } & \text { beli anđeo } \\ \text { fehéranyag } & \text { čista supstanca } \\ \text { fehérarany } & \text { belo zlato } \\ \text { fehéráru } & \text { bela roba (bela tehnika, belo meso, loj, belo } \\ \text { fehér azbeszt } & \text { pecivo, beli veš) } \\ \text { fehérbabos } & \text { beli azbest } \\ \text { fehér bábú } & \text { na bele tufnice } \\ \text { fehér bádog } & \text { bela figura } \\ \text { fehér bárány } & \text { beli lim } \\ \text { fehér barát } & \text { bela ovca } \\ \text { fehér bencések } & \text { beli fratar, monah } \\ \text { fehérbeton } & \text { beli benediktinci } \\ \text { fehérbimbós állapot } & \text { beli beton } \\ \text { fehér bolsevizmus } & \text { faza belih pupoljaka (kod razvitka cveta) } \\ & \text { beli boljševizam, krajnja desničarska ideologija }\end{array}$




$\begin{array}{ll}\text { fehérbor } & \text { belo vino } \\ \text { fehér bors } & \text { beli biber } \\ \text { fehérbe boruló } & \text { postati beo } \\ \text { fehér boszorkány } & \text { bela veštica, dobra veštica } \\ \text { fehér bot } & \text { beo štap (kao pomoćno sredstvo slepih) } \\ \text { fehér bunda } & \begin{array}{l}\text { 1. belo krzno, bela bunda, 2. snežni pejzaž } \\ \text { (metaforično) }\end{array} \\ \text { fehér cár } & \text { beli car (nezavistan vladar) } \\ \text { fehércement } & \text { beli cement } \\ \text { fehér cigányok } & \text { beli Cigani } \\ \text { fehér címkés } & \text { sa belom etiketom (za razlikovanje nekih } \\ \text { proizvoda) } & \text { beli šećer (1. rafinisani šećer, 2. heroin) } \\ \text { fehér cukor } & \text { nalog za poštansku uplatu } \\ \text { fehér csekk } & \text { žena, žensko čeljade } \\ \text { fehércseléd } & \text { bela keramička posuda, majolika } \\ \text { fehércserép } & \text { bela zvezda (1. nebesko telo, 2. monaški red, } \\ \text { fehér csillag } & \text { 3. beli beleg na čelu konja ili stoke) } \\ \text { bela čokolada } & \text { bela kost } \\ \text { fehér csokoládé } & \text { bela tišina (kao metafora smrti) } \\ \text { fehér csont } & \text { beli damast } \\ \text { fehér csönd } & \text { beli miš (1. laboratorijski miš, 2. miš koji se } \\ \text { fehér damaszt } & \text { priviđa alkoholičarima) } \\ \text { fehér egér } & \text { ravnoteža, balans bele (foto) } \\ \text { bele noći } & \text { beli slon } \\ \text { fehéregyensúly } & \text { beli čovek } \\ \text { fehér éjszaka } & \text { bela ruda, arsenopirit } \\ \text { fehér elefánt } & \text { bela Evropa } \\ \text { fehér ember } & \text { belo srebro } \\ \text { fehérérc } & \text { fehér Európa } \\ \text { fehérezüst } & \end{array}$




\begin{tabular}{|c|c|}
\hline fehér faj & bela rasa \\
\hline fehér falú & sa belim zidinama \\
\hline fehér fátyol & beli veo \\
\hline félfehér & polubeli \\
\hline fehérfém & beli metal \\
\hline fehér fény & bela svetlost \\
\hline fehér festék & bela farba \\
\hline fehér folt & bela mrlja \\
\hline fehérfolyás & belo pranje \\
\hline fehérfoszfor & beli fosfor \\
\hline fehérföld & 1. gips, 2. krečnjak, 3. bela zemljana boja \\
\hline fehér fönök & 1. beli poglavica, 2 . uticajan čovek \\
\hline fehér füst & beli dim \\
\hline fehér galamb & $\begin{array}{l}\text { beli golub (1. mir, } 2 \text {. sed čovek, } 3 \text {. zatvorenik } \\
\text { koji dugo izdržava kaznu) }\end{array}$ \\
\hline fehér gálic & galica, cink-sulfat \\
\hline fehérgalléros & $\begin{array}{l}\text { sa belim okovratnikom - čovek koji se bavi } \\
\text { intelekturalnim radom, koji je na položaju, } \\
\text { funkcioner }\end{array}$ \\
\hline Fehér Gárda & Bela garda \\
\hline fehér gyász & bela žalost \\
\hline fehér haj & bela, seda kosa kao simbol starosti \\
\hline fehérbe hajlik & $\begin{array}{l}\text { beličaste boje, koja ima primese bele, koja vuče } \\
\text { na belo }\end{array}$ \\
\hline fehérhalak & bela riba \\
\hline fehér halál & $\begin{array}{l}\text { bela smrt (1. tuberkuloza, } 2 \text {. dijabetes nastao } \\
\text { konzumacijom belog šećera, } 3 \text {. kokain) }\end{array}$ \\
\hline fehér hályog & bela mrena \\
\hline Fehér Ház. & Bela kuća \\
\hline fehér hét & bela nedelja (nedelja posle Uskrsa) \\
\hline fehérhímzés & beli vez \\
\hline fehér hó & 1. beli sneg 2 . heroin \\
\hline
\end{tabular}




\begin{tabular}{|c|c|}
\hline fehér holló & beli gavran \\
\hline fehér homok & beli pesak \\
\hline fehér hölgy & $\begin{array}{l}\text { bela dama (1. tajanstvena žena, } 2 \text {. duh u beloj } \\
\text { haljini, 3. Devica Marija, 4. žena iz reklama } \\
\text { poznatih brendova, } 5 \text {. kokain, droga) }\end{array}$ \\
\hline fehér húsok & belo meso (živina, riba) \\
\hline fehérhúsvét & $\begin{array}{l}\text { beli Uskrs (divlja ruža koja cveta oko Uskrsa, } \\
\text { Anemone nemorosa) }\end{array}$ \\
\hline fehér izzás & $\begin{array}{l}\text { belo usijanje }\left(1400^{\circ} \mathrm{C} \text { tačka usijanja nekih }\right. \\
\text { materija) }\end{array}$ \\
\hline fehérbe játszik & naginje na belo, presijava se u belo \\
\hline fehér karácsony & beli Božić (sa snegom) \\
\hline fehér kaviár & beli kavijar \\
\hline fehér kenyér & beli hleb \\
\hline fehér kerámia & bela keramika (porculan, fajans, majolika) \\
\hline fehér kereszt & beli krst (karitativna organizacija) \\
\hline fehér kesztyü & bela rukavica \\
\hline fehér király, vezér & bele figure $u$ šahu, ili junaci iz bajke \\
\hline fehér kisértet & bela utvara, duh \\
\hline fehér kóla & Šveps \\
\hline fehér kontinens & beli kontinent (1. Antarktik, 2. Evropa) \\
\hline fehér korhadás & bela trulež (bolest drveća) \\
\hline fehér könyv & bela knjiga \\
\hline fehérköpeny szindróma & sindrom belog mantila \\
\hline fehér különittmény & $\begin{array}{l}\text { beli odred (1. deo grupe koja izvodi samostalne } \\
\text { akcije, 2. sportski klubovi) }\end{array}$ \\
\hline fehér lap & prazan list \\
\hline fehér lelkü & $\begin{array}{l}\text { belog duha (1. čista duša - bezgrešan, } 2 \text {. duh u } \\
\text { belom čaršavu) }\end{array}$ \\
\hline fehér lepel & $\begin{array}{l}\text { beli čaršav (1. snežni predeo, 2. posmrtni pokrov, } \\
\text { 3. simbol nevinosti) }\end{array}$ \\
\hline fehér liliom & beli ljiljan (simbol nevinosti) \\
\hline
\end{tabular}




$\begin{array}{ll}\text { fehér lista } & \text { bela lista } \\ \text { fehér liszt } & \text { belo brašno } \\ \text { fehér ló } & \text { beo konj } \\ \text { fehér mágia } & \text { bela magija } \\ \text { fehérmáj } & \begin{array}{l}\text { bela džigerica (1. pankreas, 2. žena sa velikim } \\ \text { seksualnim potrebama, 3. cvet Parnassia } \\ \text { palustris). }\end{array} \\ \text { fehérmártás } & \text { bešamel-sos } \\ \text { fehérmárvány } & \text { beli mermer } \\ \text { fehér máz } & \text { bela glazura (1. gleđ na keramici, 2. šećerna } \\ \text { glazura na poslasticama) } \\ \text { fehér medve } & \text { beli medved } \\ \text { fehér menyasszonyi ruha } & \text { bela venčanica } \\ \text { fehér mész } & \text { beli kreč } \\ \text { fehérmosás } & \text { pranje belog veša } \\ \text { fehérmosogatás } & \text { pranje belog posuđa (tanjiri, čaše, pribor za jelo) } \\ \text { fehér mustár } & \text { beli senf (Sinapis alba). } \\ \text { fehérnemüu } & \text { beli veš, donji veš } \\ \text { fehérnép } & \text { žene } \\ \text { fehérolaj } & \text { belo ulje (visokog stepena čistoće) } \\ \text { fehérólomérc } & \text { ruda belog olova } \\ \text { fehér opál } & \text { beli opal } \\ \text { fehér óriás } & \text { beli div (1. zvezda, faza u razvoju zvezde, } \\ \text { fehérorosz } & \text { Belorus } \\ \text { fehér orrszarvú } & \text { beli nosorog životinja) } \\ \text { fehéröntvény } & \text { beli liv (liveno gvožđe nastalo brzim hlađenjem, } \\ \text { ne sadrži grafit) } & \text { beli pojas (u borilačkim sportovima) } \\ \text { fehér öv } & \text { Bela palata (na Tibetu) } \\ \text { Fehér palota } & \text { beli papir, prazan papir } \\ \text { fehér papír } & \text { fehérpecsenye }\end{array}$


fehérpenész

fehér pénz

fehér pestis

fehér por

fehér porcelán

fehér propaganda

fehérréz

fehérrizs

fehérrothadás

fehér rózsa

fehérrozsda

fehér rum

fehér sajtok

fehér sámán

fehér sas

fehérsisakosok

fehér sivatag

fehér só

fehér sólyom

fehér sport

fehér szakállú

fehér szalonna

fehérszemély

fehér szemfedő

fehér szén

fehér tea bela plesan (1. trulež, bolest biljaka, 2. plesan na nekim sirevima)

beli novac (od srebra)

bela kuga (1. tuberkuloza, 2. mali broj novorođene dece)

beli prah (1. soda za pranje, 2. droga u prahu, 3. sumnjiva materija, otrov, eksploziv)

beli porculan

bela propaganda (koji ne manipuliše svesno, otvoren je i zna se odakle potiče informacija, nastoji da bude autentičan i ne koristi laži)

alpaka

glazirani pirinač

bela trulež (gljivično oboljenje biljaka)

bela ruža

bela rđa (1. gljivično oboljenje biljaka, 2. javlja

se na pocinkovanim površinama)

svetli rum

beli sirevi

beli vrač

beli orao

beli šlemovi (dobrovoljni civilni spasioci)

bela pustinja

kuhinjska so, Himalajska bela so

beli soko

beli sport, tenis

belobradi, Deda Mraz

bela slanina

žena

beli pokrov

hidrocentrala

beli čaj 


\begin{tabular}{|c|c|}
\hline fehér tégla & bela cigla \\
\hline fehér telepes & beli doseljenik \\
\hline fehérterror & $\begin{array}{l}\text { beli teror (odmazda nekon revolucije, vraćanje } \\
\text { starog režima) }\end{array}$ \\
\hline fehér tinta & $\begin{array}{l}\text { beli tuš (za retuširanje, grafiku, specijalnu } \\
\text { štampu) }\end{array}$ \\
\hline fehér törpe & $\begin{array}{l}\text { beli patuljak (zvezda u zadnjoj fazi svog } \\
\text { nastanka) }\end{array}$ \\
\hline fehérben úszik & obasjan belom bojom \\
\hline fehér üveg & $\begin{array}{l}\text { 1. obično, nebojeno, prozirno staklo, } \\
\text { 2. peskareno staklo }\end{array}$ \\
\hline fehérvár & bela tvrđava, čest sastavni deo naziva gradova \\
\hline fehérvas & belo gvozđe \\
\hline fehérvasárnap & bela nedelja, nedelja posle Uskrsa \\
\hline fehérvérüség & leukemija \\
\hline fehér vérsejt & bela krvna zrnca \\
\hline fehér vértanú & $\begin{array}{l}\text { beskrvno mučeništvo, beli mučenik umire } \\
\text { prirodnom smrću, ali prethodno mučen }\end{array}$ \\
\hline fehér viselet & bela nošnja \\
\hline fehérzafir & beli safir \\
\hline fehérzaj & $\begin{array}{l}\text { bela buka, pojam u audio-tehnici, ujednačena } \\
\text { buka }\end{array}$ \\
\hline fehér zászló & bela zastava \\
\hline fehérzoknis & muškarac bez manira i ukusa u oblačenju \\
\hline három fehér méreg & tri bela otrova: so, brašno, šećer \\
\hline herceg fehér lovon & princ na belom konju \\
\hline tejfehér köd & gusta magla \\
\hline tojásfehérje & belance jajeta \\
\hline vakitó fehér & zaslepljujuće bela \\
\hline
\end{tabular}




\section{Bibliográfia}

Bárdosi Vilmos 2012. A magyar szólások, közmondások értelmező szótára fogalomköri szómutatóval. Budapest: Tinta Könyvkiadó.

Berlin, Brent - Kay, Paul 1969. Basic Color Terms: Their Universality and Evolution. Berkeley: Univerity of California Press.

Forgács Tamás 2003. Magyar szólások és közmondások szótára. Budapest: Tinta Könyvkiadó.

Földvári Melinda: Színszótár http://www.szintan.hu/ (utoljára megtekintve: 2019.07.12.)

HTML színek és kódok http://htmlinfo.polyhistor.hu/js13ref/colors.htm/ (utoljára megtekintve: 2019.07.22.)

ISCC-NBS Dictonary of Colour Names http://www.tx4.us/nbs/nbs-a.htm/ (utoljára megtekintve: 2019.07.20.)

Ivić, Milka 1995. O nazivima boja. In: Milka Ivić O zelenom konju - novi lingvistički ogledi. Beograd: Slovograf. 9-101.

Ivić, Milka 1999. Belo kao lingvistički i kulturološki problem. Južnoslovenski filolog $55,1-19$.

Litovkina T. Anna 2010. Magyar közmondások nagyszótára. Budapest: Tinta Könyvkiadó.

Matešić, Josip 1982. Frazeološki rječnik hrvatskoga ili srpskoga jezika. Zagreb: Školska knjiga.

ÉKSz 2003. Magyar Értelmező Kéziszótár. Budapest: Akadémiai Kiadó.

O. Nagy Gábor 1966. Magyar szólások és közmondások. Budapest: Gondolat.

Otašević, Đorđe 2012. Frazeološki rečnik srpskog jezika. Novi Sad: Prometej.

RMS 2007. Rečnik srpskoga jezika Novi Sad: Matica srpska.

Vlajković, Ivana-Stamenković, Dušan 2013. Metaphorical Extensions of the Colour Terms Black and White in English and Serbian. In: Šesti međunarodni interdiscipliniranni simpozijum Susret kultura-Zbornik radova. Novi Sad: Filozofski fakultet. 547-558. 


\title{
The Colour 'White' in Hungarian and Serbian
}

Edit Andrić, University of Novi Sad, Faculty of Philosophy, Department of Hungarian Studies

\begin{abstract}
Colours are all around us, but the terms used for naming the shades of the basic colours show significant crosslinguistic differences. The author has already offered a contrastive analysis of several colour terms in Hungarian and Serbian. Therefore, this paper explores the manifestations of the colour 'white' and provides the analysis of the terms used for this colour in Hungarian and Serbian, establishing the exact semantics of the lexemes which denote the colour 'white', the origin of these words, and presents an overview of the shades of 'white' in the languages under scrutiny.

This study also deals with the symbolism of the colour 'white' in Hungarian and Serbian. In particular, the paper analyses the forms derived from the colour terms feher and beo. The phrases containing the colour 'white' are often fixed expressions and are used as such in everyday communication. This is why the paper also includes an overview of collocations and phraseological units that contain this basic colour in the languages analysed, thereby illustrating the different ways in which 'white' is conceptualized in the two cultures.

The paper is primarily based on colour terms used in Hungarian, Serbian equivalents of which are found in the literature, in colloquial language, and on the Internet.
\end{abstract}

Keywords: colour terms, shades, fehér, beo, phraseology, Hungarian, Serbian.

\section{Bela boja u mađarskom i srpskom jeziku}

Edita Andrić, Univerzitet u Novom Sadu, Filozofski fakultet, Katedra za hungarologiju

\section{Sažetak}

Boje se nalaze svude oko nas i univerzalno svojstvo čoveka je da pomoću čula vida može da ih razlikuje. Međutim, nazivi za nijanse osnovnih boja se razlikuju u jezicima. Autorka rada se u više navrata bavila nazivima za boje u mađarskom i srpskom jeziku, stoga u ovom radu istražuje pojavu bele i termine koji se koriste za ovu boju u pomenutim jezicima, baveći se značenjima tih leksema, njihovim poreklom, i daje pregled nijansi bele u mađarskom jeziku, nastojeći da se pronađu prevodni ekvivalenti u srpskom. Posebna se pažnja poklanja derivacionom potencijalu reči fehér, ali i kognitivno-lingvističkom značaju bele boje. U svakodnevnoj komunikaciji su često prisutni izrazi sa odrednicom feher i beo, te se rad posebno fokusira na frazologije i na kolokacijske strukture, ukazujući na sličnosti i razlike u jezicima koji su predmet analize. Građa se prvenstveno bazira na mađarskim terminima iz internet baze podataka, i na leksemama i izrazima iz rečnika, odnosno na njihovim prevodima na srpski jezik.

Ključne reči: nazivi za boje, nijanse, fehér, beo, frazeologija, mađarski jezik, srpski jezik. 